\title{
ENSAIOS
}

\section{A GREVE COMO DIREITO \\ FUNDAMENTAL}

Recebimento do artigo: 30/09/2006

Aprovado em: 10/10/2006

\section{Domingos Sávio Zainaghi}

\section{Introdução}

A greve é um dos meios de autodefesa mais utilizados pelo trabalhador, e o exercício deste direito mostra o grau de democracia de uma sociedade, constituindo-se num fenômeno da sociedade contemporânea.

O termo greve deriva do francês Grève, que significa gravetos. Havia uma praça em Paris onde os trabalhadores se reuniam para discutir condições de trabalho. Este local, por ser próximo ao rio Sena, que com as enchentes transbordava, ficava cheio de gravetos e entulhos; daí o termo Place de Grève.

O termo não é universal, sendo que encontramos vários vocábulos noutros idiomas para indicar o fenômeno.

Em espanhol usa-se o termo buelga em inglês strike $\sim$ em italiano sciopero $\sim$ em alemão streik.

Não obstante ter-se afirmado que a greve é um fenômeno contemporâneo, historiadores afirmam que movimentos revoltosos da antiguidade seriam atos de greve, como, por exemplo, o êxodo dos hebreus que deixaram o trabalho escravo a que eram submetidos no Egito. Aliás, apenas para se pensar como tal greve foi boa, seu líder teria sido Deus!

As paralisações do trabalho foram consideradas em muitos momentos da história como atos criminosos, puníveis pela legislação penal, como ocorreu na França das corporações de ofício e até mesmo no Brasil, no período do Estado Novo, sendo que a Constituição de 1937 assim pregava

Art $139-\ldots$

A greve e o lock-out são declarados recursos anti-sociais nocivos ao trabalho e ao capital e incompatíveis com os superiores interesses da produção nacional.

E a legislação infraconstitucional a tipificava como crime (Dec. Lei n. 43138), além de ser motivo para dispensa do empregado por justa causa, a prática da greve.

Somente em 1946, com a nova constituição, é que a greve foi reconhecida como um direito dos trabalhadores

Art 158 - É reconhecido o direito de greve, cujo exercício a lei regulará. 

público e nas atividades essenciais.

A Constituição atual trata da greve no artigo 9, dando a esse direito uma amplitude nunca antes reconhecida:

Art. $9^{\circ}$ É assegurado o direito de greve, competindo aos trabalhadores decidir sobre a oportunidade de exercê-lo e sobre os interesses que devam por meio dele defender.

$\int 1^{\circ}$ - A lei definirá os serviços ou atividades essenciais e disporá sobre o atendimento das necessidades inadiáveis da comunidade. $\int 2^{\circ}$ - Os abusos cometidos sujeitam os responsáveis às penas da lei.

E, ainda, estendeu-se aos servidores públicos o direito de greve. Art. 37...

VI - é garantido ao servidor público civil o direito à livre associação sindical;

VII - o direito de greve será exercido nos termos e nos limites definidos em lei específica;

Portanto, a greve é hoje um direito fundamental do trabalhador, seja ela da área privada ou do serviço público.

\section{Conceito}

Greve é a suspensão temporária e coletiva do contrato de trabalho por iniciativa dos empregados, visando à melhoria das condições de trabalho.

\section{Natureza jurídica}

A greve é um direito individual, mas que se exerce coletivamente. É uma forma de solução de conflitos trabalhistas por autodefesa. Como afirmado acima, no Direito brasileiro é motivo de suspensão do contrato de trabalho, ou seja, durante a greve os trabalhadores não prestam serviços, os empregadores não pagam salários e o período de paralisação, como regra, não é computado como de tempo de serviço.

\section{Legislação infraconstitucional}

Logo após a promulgação da Constituição de 1988, foi editada a Lei n. 7.783, de 28 de junho de 1989, que regulamentou as normas constitucionais.

Pela lei de greve, só será legítimo o exercício do direito depois de frustradas a negociação coletiva ou a impossibilidade de recurso à via arbitral, e, ainda, devem ser notificados o sindicato patronal e os empregadores com 48 horas de antecedência. 
Durante a greve são assegurados aos grevistas o emprego de meios pacíficos tendentes a persuadir ou aliciar os trabalhadores a aderirem à greve, a arrecadação de fundos e a livre divulgação do movimento.

Próibe a lei que as empresas adotem métodos não só para constranger os empregados ao comparecimento ao trabalho, bem como capazes de frustrar a divulgação do movimento.

Por outro lado, as manifestações e atos de persuasão dos grevistas não poderão impedir o acesso ao trabalho nem causar dano à propriedade ou pessoa.

Os contratos de trabalho não podem ser rescindidos durante a greve, mas a lei determinou que, durante a paralisação, o sindicato ou a comissão de negociações, mediante acordo com a entidade patronal ou diretamente com o empregador, mantenha em atividade equipes de empregados com o propósito de assegurar os serviços cuja paralisação resultem em prejuízo irreparável, pela deterioração irreversível de bens, máquinas e equipamentos, bem como manutenção daqueles essenciais à retomada dos trabalhos da empresa quando da cessação do movimento. Caso não haja acordo, é assegurado aos empregadores, enquanto perdurar a greve, a contratação dos serviços necessários à manutenção mencionada.

\section{Serviços essenciais}

A Constituição de 1988 trouxe como grande avanço no tocante à greve, a permissão de seu exercício nas atividades e serviços essenciais, mas determina que sindicatos, empregados e empregadores, atendem nestes serviços, as necessidades inadiáveis da comunidade.

E o artigo 10 da lei traz o rol dos serviços essenciais:

Art. 10 São considerados serviços ou atividades essenciais:

I - tratamento e abastecimento de água; produção e distribuição de energia elétrica, gás e combustíveis;

II - assistência médica e hospitalar;

III - distribuição e comercialização de medicamentos e alimentos;

IV - funerários;

$\mathrm{V}$ - transporte coletivo;

VI - captação e tratamento de esgoto e lixo;

VII - telecomunicações;

VIII - guarda, uso e controle de substâncias radioativas, equipamentos e materiais nucleares;

IX - processamento de dados ligados a serviços essenciais;

$\mathrm{X}$ - controle de tráfego aéreo;

XI compensação bancária.

A lei afirma que necessidades inadiáveis são aquelas que, se não atendidas, colocam em perigo iminente a sobrevivência, a saúde ou a segurança da população. 
Nas atividades essenciais, os sindicatos devem comunicar a decisão de iniciar a greve aos empregadores e aos usuários com 72 horas de antecedência, sob pena de se considerar abuso do direito de greve.

\section{Greve no serviço público}

A Constituição de 1988 autorizou a greve nos serviços públicos, consoante o previsto no artigo 37.

Ocorre, entretanto, que a Lei Maior delegou à lei complementar a regulamentação do direito.

A Emenda Constitucional n. 19 alterou a previsão supra, e está hoje assim redigido o artigo 37

VII - o direito de greve será exercido nos termos e nos limites definidos em lei específica.

De qualquer maneira, até hoje, outubro de 2006, a lei de que trata a Constituição não foi redigida.

Em razão da ausência de lei, a bem da verdade, os servidores públicos não poderiam entrar em greve, mas entram, e nos últimos anos o judiciário é que tem tido grande trabalho para dirimir essas questões, pois o Brasil não ratificou norma da OIT Organização Internacional do Trabalho que prevê a negociação coletiva na área pública, mas a negociação efetivamente ocorre, e, em muitos casos, após a negociação com o Poder Executivo é "encomendada" uma lei para conceder o pedido pelos servidores. Uma situação Kafkiana!

\section{Conclusão}

A greve é um direito fundamental, base de um Estado civilizado e democrático. Só as ditaduras não admitem a greve.

No Brasil o direito de greve é novo, pois somente em 1946 é que a Constituição promulgada naquele ano o autorizou, deixando para o legislador ordinário a tarefa de regulamentar tal direito, o que só veio a ocorrer em 1964, ou seja, no início do regime militar que na prática cerceou o exercício desse direito.

Com a Carta de 1988, o Direito de Greve foi amplamente autorizado, ou seja, um Direito Fundamental basilar da democracia brasileira reconhecido aos trabalhadores. 